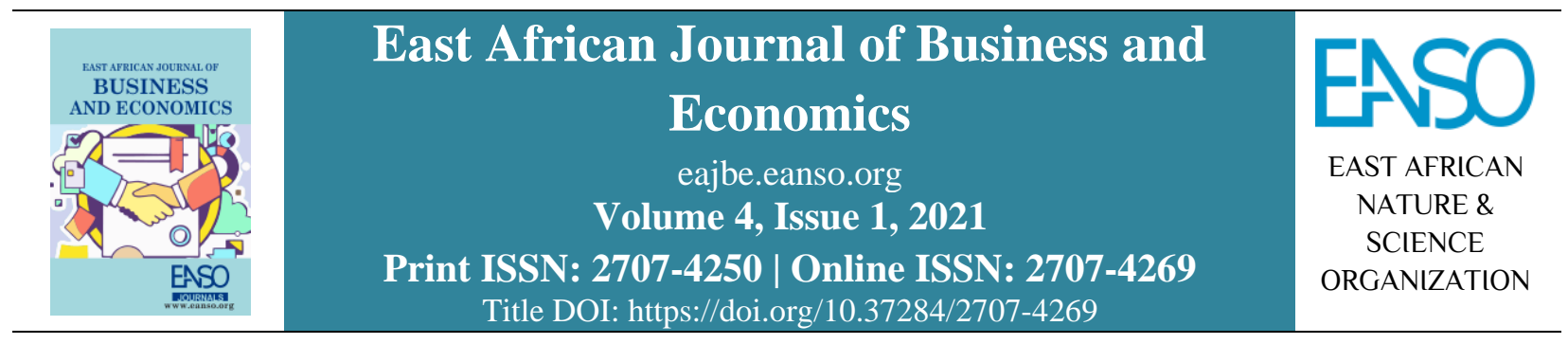

Original Article

\title{
The Relationship between Credit Risk and Financial Performance: Evidence from Commercial Banks in Tanzania.
}

\author{
Ahmada Kaimu ${ }^{1 *} \&$ Dr. Seif Muba \\ ${ }^{1}$ Mzumbe University Tanzania, P. O. Box 1 , Morogoro, Tanzania. \\ *Correspondence ORCID ID: https://orcid.org/0000-0002-0506-3962; email: kaimuahmada@yahoo.com
}

Article DOI: https://doi.org/10.37284/eajbe.4.1.478

Date Published: ABSTRACT

23 November 2021 This research study purposed to determine the relationships between credit risks and the performance of commercial banks in Tanzania. Generally, the

Keywords: study aimed to establish the relationship between credit risk and financial performance in Tanzanian Banks. Specifically, to determine if the long-run

Non Perfroming Loans, relationship between credit risk and performance existed and investigated

Return On Asset,

Capital Adequacy Ratio,

Credit Risk,

if credit risk and financial performance existed with a causal relationship in

Tanzanian Banks. The research collected secondary data samples of 15 commercial banks in Tanzania from 2005-2019. This study adopted an explanatory approach to fulfil the above objectives. Both fixed and random

Financial Perfromance, Long Run Relationship,

Ganger Causality. effects models were engaged to determine the relationship. Hausman Test executed to determine the appropriate model. In the model, NPLR, LLPR, CAR, and BAS were used as the credit risk proxies, while return on asset (ROA) was used as the dependent variable. The findings reveal that the credit risk has both negative and positive relationships with the proxies used. The performance was inversely significant with NPLR and negatively insignificant with LLPR, while positively significant with CAR and positively insignificant with LBAS. The study concluded that the credit risk proxies, i.e., there was a significant relationship between NPLR and CAR with the commercial banks' performance in Tanzania. Furthermore, the researchers concluded that the long-run relationship existed on the variables in the study, while granger causality existed in all variables except LLPR, i.e., Credit risk proxies except LLPR can granger cause the performance of commercial banks while the granger causality reveals no causal relationship among independent variables themselves. The study recommended that commercial banks in Tanzania should put more emphasis on handling credit risk and management of capital adequacy so as to have better financial performance. 
East African Journal of Business and Economics, Volume 4, Issue 1, 2021

Article DOI: https://doi.org/10.37284/eajbe.4.1.478

\section{APA CITATION}

Kaimu, A., \& Muba, S. (2021). The Relationship between Credit Risk and Financial Performance: Evidence from Commercial Banks in Tanzania. East African Journal of Business and Economics, 4(1), 22-33. https://doi.org/10.37284/eajbe.4.1.478

\section{CHICAGO CITATION}

Kaimu, Ahmada \& Seif Muba. 2021. "The Relationship between Credit Risk and Financial Performance: Evidence from Commercial Banks in Tanzania". East African Journal of Business and Economics 4 (1), 22-33. https://doi.org/10.37284/eajbe.4.1.478.

\section{HARVARD CITATION}

Kaimu, A., \& Muba, S. (2021) "The Relationship between Credit Risk and Financial Performance: Evidence from Commercial Banks in Tanzania”, East African Journal of Business and Economics, 4(1), pp. 22-33. doi: 10.37284/eajbe.4.1.478.

\section{IEEE CITATION}

A. Kaimu, \& S. Muba, "The Relationship between Credit Risk and Financial Performance: Evidence from Commercial Banks in Tanzania", EAJBE, vol. 4, no. 1, pp. 22-33, Nov. 2021.

\section{MLA CITATION}

Kaimu, Ahmada \& Seif Muba. "The Relationship between Credit Risk and Financial Performance: Evidence from Commercial Banks in Tanzania". East African Journal of Business and Economics, Vol. 4, no. 1, Nov. 2021, pp. 22-33, doi:10.37284/eajbe.4.1.478.

\section{INTRODUCTION}

Banks are usually exposed to more than a few types of risks. According to (BOT, Risk Management Guidelines, 2010), the six most common risks in the sector of banking will be covered by these guidelines such as liquidity risk, credit risk, market risk, operational risk, strategic risk, and compliance risk. All risks are very important to be managed properly to guarantee stability and maintain the proper sound of the financial system in the country, however among mentioned risks; one of the risks which may most lead to bank failures are credit risk since credit accommodations are the core revenue source of the banks and with this core functions, credit risk will be one of their key obstacles to attain their maximum profit goals.

The analysis of the NPL trends during the period of 2005 to 2019 had not been below the required BOT recommended threshold of $5 \%$, despite this, all banking sector performance continued to be satisfactory as revealed by the financial soundness indicator as reported on (BOT, Annual Report, 2019) with asset quality of the sector improved as evidenced with slightly decrease in the NPL ratio of $9.58 \%$ from $10.51 \%$ reported in the previous year 2018 and $11.90 \%$ as highest NPL recorded in 2017 during the period of 2005-2019 in which both of them being above the threshold.

To understand the researchers' knowledge, there are few previous research that has been done in Tanzania's banking sectors on the correlation between credit risks and financial performance. The few mentioned research imply that there was no exact conclusion that had been drawn on the link between credit risk and financial performance; hence the motivation of the research is to fill this gap in the literature. The general objective of the study was to establish the relationship between credit risk and financial performance of commercial banks in Tanzania over the period of 2005 to 2019, while specifically the study determined if there is a long-run relationship between credit risk and commercial banks financial performance in Tanzania and investigate if there is a causal relationship between credit risk and commercial banks financial performance in Tanzania. The study covered the research gap and answered the questions below.

RQ1. Is there a long-run relationship between credit risk and financial performance of commercial banks in Tanzania from 2005 2019 ? 
RQ2. Is there a causal relationship between credit risk and other variables on commercial banks' financial performance in Tanzania from 2005 - 2019?

\section{LITERATURE REVIEW}

\section{Theoretical Review}

\section{The Credit Risk Theory}

It has been noted the cause of credit risk is the default risk. Default risk is the risk that borrowers or lenders will not be able to fulfil the contractual commitments once they fall due. This risk is mainly that of the borrower and includes lost interest and principal. Disruption loss can be partial or total and it can occur in a variety of circumstances, such as an insolvent bank that has failed to return funds to a depositor.

\section{Asymmetric Information Theory}

Information asymmetry theory was first applied by Akerlof (1970). Indicates asymmetric information exists when one party in a transactional relationship has more information about the transaction than the other party. Lenders offering credit facilities to borrowers face the uncertainty of loan repayment. Lenders cannot analyse the characteristics and behaviours of the borrower and for that reason, and it is difficult to evaluate the borrower. Banks may find it difficult to distinguish credit-worthy borrowers from bad borrowers, which may result in adverse selection and moral hazards problems (Lotto, 2018).

\section{Empirical Review}

This part of the study summarises a review of earlier studies that prior researchers and concluded the following four relationships.

Credit risk and Financial Performance: Positive Relationship
Boahene et al. (2012) examined the relationship between credit risk and profitability of some selected banks in Ghana. Panel data was studied using the fixed effects approach for a period of 5 years from a sample of 6 selected commercial banks (2005 to 2009). Credit risk proxies used revealed a significant positive relationship with bank profitability. In the same vein, a positive relationship between credit risk and performance was concluded by Cheng et al. (2020), Afriyie and Akotey (2013), Li and Zou (2016), just a few to mention.

\section{Credit risk and Financial Performance: Negative Relationship}

Hosna et al. (2009) carried out research to describe the relationship between credit risk management and profitability for four commercial banks in Sweden. SPSS was used to analyse the quantitative data. The findings concluded that NPLR had a significant impact compared to CAR as credit risk management indicators on profitability (ROE) in all 4 samples of the banks. In the same vein, a negative relationship between credit risk and performance was concluded by Kaaya and Pastory (2013), Bono (2020), Munangi and Bongani (2020), Takang and Ntui (2008).

\section{Credit risk and Financial Performance: Negative and Positive Relationship}

Gizaw et al. (2015) on their research examined the impact of credit risk on the profitability performance of commercial banks in Ethiopia. Using credit risk measures such as NPL, CAR, and LLPR while performance indicators were ROE and ROA. The findings revealed that credit measures, i.e., LLP, NPL, and CAR have a significant relationship with the profitability of commercial banks in Ethiopia. Concluded that Loan Loss provision has a significant and positive relationship with profitability as proxies on both ROA and ROE while on the same study, the NPL concluded a negative significance with ROA and ROE. In the 
same vein, a negative and positive relationship between credit risk and performance was concluded by Anwen and Bari (2015) and Alshatti (2015).

\section{Credit risk and Financial Performance: No Relationship}

Kithinji (2010) examined the impact between credit risk management and the commercial bank profitability operating in Kenya. The data used in the study were extracted from 2004-2008 published audited report. The findings revealed that there is no relationship between credit risk measures, i.e., NPL with the banks' performance. In the same vein, no relationship between credit risk and performance was concluded by Kolapo et al. (2012) and Daba (2015).

\section{Conceptual Framework}

The following conceptual model in Figure 1 is framed based on the study's main objective, the relationship between credit risk as measured by NPL, LLPR, BAS, and CAR, and bank performance measure by ROA.

\section{Figure 1: Conceptual Framework}

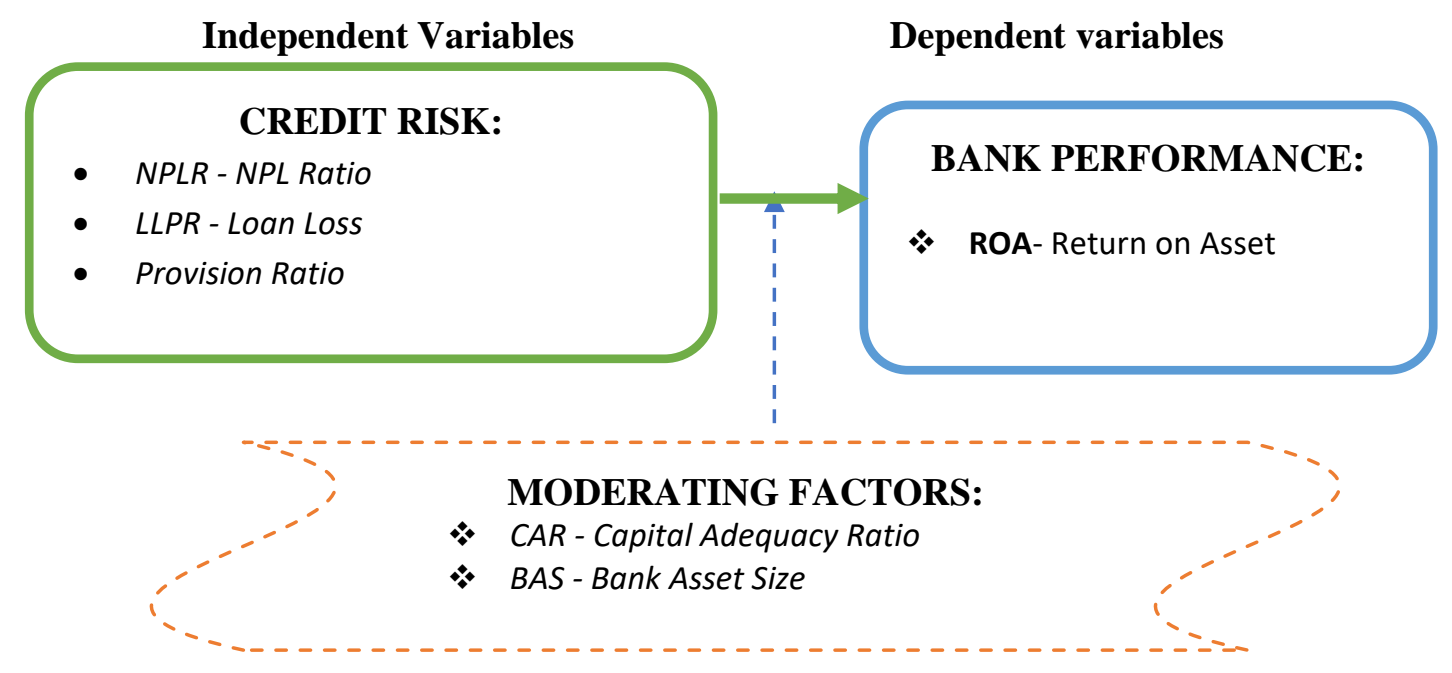

\section{Control Variables}

\section{METHODOLOGY OF THE STUDY}

\section{Research Design}

Both explanatory and descriptive research was engaged in our study similar to previous studies such as those done by Laar and Adjei (2020) and Poudel (2018). The population included all 38 Tanzanian licensed commercial banks.

\section{Sample Size and Type and Sources of Data}

The study used a sample of 15 out of 38 of the commercial banks from the targeted population to be analysed for the period of 2005 to 2019 . The secondary data was used to attain its study objective. The required secondary data were obtained from annual financial statements and were annually panelled.

\section{Regression Model}

The empirical model to be estimated will be written as follows:

$$
\begin{aligned}
& R O A_{i t}=\alpha+\beta_{1} N P L R_{1 i t}+\beta_{2} L L P R_{2 i t}+\beta_{3} \\
& C A R_{3 i t}+\beta_{4} B A S_{4 i t}+\mathrm{e} \ldots \ldots \ldots \ldots \ldots . . .1(1)
\end{aligned}
$$

Where: 
The subscript $i$ denote the cross-sectional (sample selected banks) and subscript $t$ refer to the timeseries dimension (2005 - 2019). $Y_{i t}=\mathrm{ROA}$ as Dependent variable, $\alpha=$ Intercept (Constant) term, $X_{1}=$ Non-performing Loans as Independent variables, $X_{2}=$ Loan Loss Provision Ratio as Independent variables, $X_{3}=$ Capital Adequacy Ratio as control variables, $X_{4}=$ Bank Asset Size as control variables, $e=$ Error term, $\beta_{1}-\beta_{4}=$ coefficients of independent variables which suggests that a unit increase in any of credit risk variables will lead to a unit decrease $(<0)$ or increase $(>0)$ in the dependent variable

\section{FINDINGS}

\section{Descriptive Statistics of Variables}

Table 1 below shows the summary statistics of selected variables. ROA ranges from a minimum of -0.0406 to a maximum of 0.092 and a small standard deviation of 0.017 , leading to the conclusion that the performance between the commercial banks in Tanzania is almost comparable. For the last 15 years, the average NPL in Tanzania's commercial banking business was $5.2 \%$, with a standard deviation of $3.77 \%$. The difference between the minimum $(0 \%)$ and greatest $(25.3 \%)$ values, as well as the standard deviation, showed that the NPL ratio was very variable.

Table 1: Summary of Descriptive Statistics Panel Data

\begin{tabular}{llllllll}
\hline Variable & Mean & Min & Max & Std. Dev & Skewness & Kurtosis & Obs \\
\hline ROA & 0.0206 & -0.0406 & 0.0920 & 0.0170 & 0.3452 & 4.9450 & 225 \\
NPLR & 0.0520 & 0.0000 & 0.2530 & 0.0377 & 1.2870 & 6.1015 & 225 \\
LLPR & 0.0296 & 0.0002 & 0.1289 & 0.0286 & 1.4606 & 4.4181 & 225 \\
CAR & 0.1836 & 0.0779 & 0.5900 & 0.0608 & 2.1249 & 13.7394 & 225 \\
LBAS & 13.1265 & 9.8393 & 15.7022 & 1.2077 & -0.2288 & 2.7268 & 225 \\
\hline
\end{tabular}

ROA = Return on asset $;$ NPLR $=$ Non-performing Loans; $L L P R=$ Loan Loss Provision Ratio $;$ CAR = Capital Adequacy Ratio; LBAS = Natural Logarithm of Bank Asset

Source: Annual reports from the sample of selected Commercial Banks (2005-2019)

\section{Correlation Analysis}

In this section, the focus is placed on analysing the correlations between the variables engaged in this study. Mengistu (2018) cited that a correlation coefficient above 0.80 between independent variables should be corrected as it is a sign of multicollinearity. The correlations of the variables used are presented and discussed in Table 2:

Table 2: Correlation Matrix between credit risk proxies and ROA

\begin{tabular}{llllll}
\hline & ROA & NPL & LLPR & CAR & LBAS \\
\hline ROA & 1.0000 & & & & \\
NPL & $-0.2684^{*}$ & 1.0000 & & & \\
LLPR & -0.0405 & $0.1851^{*}$ & 1.0000 & & \\
CAR & $0.2365^{*}$ & -0.0760 & $0.1649^{*}$ & 1.0000 & \\
LBAS & 0.1160 & $0.2679^{*}$ & -0.0587 & 0.0173 & 1.0000 \\
\hline
\end{tabular}

Key: P-values in brackets and * Present 0.05 significant level of correlation

Source: Annual reports of selected Banks and results were generated from STATA 13 
East African Journal of Business and Economics, Volume 4, Issue 1, 2021

Article DOI: https://doi.org/10.37284/eajbe.4.1.478

\section{Panel Unit root Test}

This study engaged the following test; Breitung Unit root and Levin-Lin-Chu unit-root test to determine whether the existence of stationary and integrated to the same order for all study variables.
Null hypothesis: $\left(\boldsymbol{H}_{\mathbf{0}}\right)$ Panels contain unit roots - Accept $\boldsymbol{H}_{\mathbf{0}}$ If (Sig. F) > 5\%.

Alternative hypothesis: $\left(\mathrm{H}_{1}\right)$ Panels are stationary - Accept $\boldsymbol{H}_{\mathbf{1}}$ If (Sig. F) $<5 \%$

Table 3: Method Levin Lin- Chu \& Breitung Decision

\begin{tabular}{llll}
\hline Method & Levin Lin- Chu & Breitung & Decision \\
\cline { 2 - 3 } & p-value & p-value & \\
\hline ROA & 0.0209 & 0.0003 & Reject Ho \\
NPLR & 0.0348 & 0.0299 & Reject Ho \\
LLPR & 0.0008 & 0.0018 & Reject Ho \\
CAR & 0.0000 & 0.0065 & Reject Ho \\
LBAS & 0.0000 & 0.0014 & Reject Ho \\
\hline
\end{tabular}

Source: Annual reports from the sample of selected Commercial Banks (2005-2019)

\section{Model Selection}

The model application selection will be based on the Hausman test.

Fixed Effects Model
Fixed effect model is the model used by the researcher to examine panel data if the objective is to control omitted variables that differ between cases but vary over time which implies timeinvariant (Tuladhar, 2017).

Table 4: Fixed Effect model

\begin{tabular}{lllll}
\hline \multicolumn{2}{l}{ Dependent variables: ROA } & & & \\
\hline Variables & Coefficient & Std Error & t-statistic & P-Values \\
\hline NPLR & -0.0855433 & 0.0332415 & -2.57 & 0.011 \\
LLPR & -0.0238776 & 0.0469329 & -0.51 & 0.611 \\
CAR & 0.0725843 & 0.0202451 & 3.59 & 0.000 \\
LBAS & 0.0013421 & 0.0015736 & -0.85 & 0.395 \\
Constant & 0.0300322 & 0.0211203 & 1.42 & 0.157 \\
R^2 & 0.0818 & & & \\
\hline
\end{tabular}

Source: Annual reports from the sample of selected Commercial Banks (2005-2019)

The Fixed effects (within) regression were specified as follows:

ROA $=0.0300-0.0855$ NPLR -0.0239 LLPR + $0.0726 \mathbf{C A R}+0.00134 \mathbf{L B A S}+\mathbf{e}$

\section{Random Effects Model}

This model is engaged when researchers want to control omitted variables that change over time but are constant between cases implying that the variations will be presumed to be uncorrelated and random with the independent variables (Tuladhar, 2017). 
East African Journal of Business and Economics, Volume 4, Issue 1, 2021

Article DOI: https://doi.org/10.37284/eajbe.4.1.478

Table 5: Random Effect Model

\begin{tabular}{lllll}
\hline \multicolumn{2}{l}{ Dependent variables: ROA } & & & \\
\hline Variables & Coefficient & Std Error & t-statistic & P-Values \\
\hline NPLR & -0.1224732 & 0.0306915 & -3.99 & 0.000 \\
LLPR & -0.0101285 & 0.0408950 & -0.25 & 0.804 \\
CAR & 0.0662642 & 0.0183959 & 3.60 & 0.000 \\
LBAS & 0.0019239 & 0.0010552 & 1.82 & 0.068 \\
Constant & -0.0101659 & 0.0140541 & -0.72 & 0.469 \\
R^2 & 0.1506 & & & \\
\hline
\end{tabular}

Source: Annual reports from the sample of selected Commercial Banks (2005-2019)

The Random-effects GLS regression were specified as follows:

$$
\begin{aligned}
& \text { ROA }=-0.01016-0.1225 \text { NPLR }-0.0101 \text { LLPR } \\
& +0.0663 \text { CAR }+0.00192 \text { LBAS }+\mathbf{e}
\end{aligned}
$$

\section{The Hausman Test}

The test was performed to establish the suitable model in the panel data studies as it helps the researchers in choosing the best fitting model to perform regression analysis. When there is a need to find the effect of independent variables on dependent variables, 2 models can be used in regression analysis which is the Random Effect Model and Fixed Effect Model (Boahene et al., 2012).

Null hypothesis: $\left(\boldsymbol{H}_{\mathbf{0}}\right)$ Random Effect Model is appropriate - Accept $\boldsymbol{H}_{\mathbf{0}}$ If (Sig. F) $>5 \%$.

Alternative hypothesis: $\left(\boldsymbol{H}_{1}\right)$ Select Fixed Effect Model is appropriate - Accept $\boldsymbol{H}_{\mathbf{1}}$ If (Sig. F) $<5 \%$.

Table 6: Hausman Test

\begin{tabular}{lllll}
\hline \multicolumn{7}{l}{ Coefficients } & & & \\
\hline & $(\mathbf{b})$ & $(\mathbf{B})$ & $\mathbf{( b - B )}$ & Prob. \\
\hline Variable & Fixed effect & Random effect & Difference & S.E \\
\hline NPLR & -0.0855433 & -0.1224732 & 0.0369299 & 0.0127682 \\
LLPR & -0.0238776 & -0.0101285 & -0.0137491 & 0.0230281 \\
CAR & 0.0725843 & 0.0662642 & 0.0063201 & 0.0084529 \\
LBAS & -0.0013421 & 0.0192390 & -0.0205811 & 0.0011674 \\
Prob $>$ chi2 $=0.0049 \quad$ Chi $(4)=14.91$ & & \\
\hline
\end{tabular}

Source: Annual reports from the sample of selected Commercial Banks (2005-2019)

At a 5\% level of significance, the null hypothesis is rejected because the p-value is less than 5\% (0.0049). As a result, the preferred model will be the FE model against the RE model. Therefore, the interpretation relationship would be on the fixed effects model as presented in Table 6.

\section{Testing the Long-Run Relationship Using Johansen's Co Integration Test}

The Johansen co-integration procedure is based on maximum Eigenvalue, trace statistics, and the critical value. The result is reported in Table 7:

Null hypothesis: $\left(\boldsymbol{H}_{\mathbf{0}}\right)$ there is no long-run relationship between variables (no cointegrating 
East African Journal of Business and Economics, Volume 4, Issue 1, 2021

Article DOI: https://doi.org/10.37284/eajbe.4.1.478

equation) - Accept $\boldsymbol{H}_{\mathbf{0}}$ If the Trace and Max

statistics $<5 \%$ critical value.
Alternative hypothesis: $\left(\boldsymbol{H}_{1}\right)$ there is a long-run relationship between variables $\left(\left(\boldsymbol{H}_{\mathbf{0}}\right)\right.$ is not true $)$ - Accept $\boldsymbol{H}_{\mathbf{1}}$ If the Trace and Max statistics > $5 \%$ critical value.

Table 7: Johansen Tests for Cointegration

\begin{tabular}{llllll}
\hline \multicolumn{2}{l}{ Trend: Constant } & \multicolumn{3}{l}{ Number of Observation $=$} & $\mathbf{2 2 3}$ \\
\hline \multicolumn{2}{l}{ Sample: 2007 - 2019 } & & & Lags $=$ & $\mathbf{2}$ \\
\hline maximum rank & parms & LL & Eigen value & Trace statistic & $\mathbf{5 \%}$ critical value \\
\hline 0 & 30 & 1701.001 &. & 218.9576 & 68.52 \\
1 & 39 & 1736.8324 & 0.27484 & 147.2948 & 47.21 \\
2 & 46 & 1766.4325 & 0.23316 & $88.0946^{*}$ & 29.68 \\
maximum rank & parms & LL & Eigen value & Max statistic & $5 \%$ critical value \\
0 & 30 & 1701.001 &. & 71.6627 & 33.46 \\
1 & 39 & 1736.8324 & 0.27484 & 59.2002 & 27.07 \\
2 & 46 & 1766.4325 & 0.23316 & $50.5175^{*}$ & 20.97 \\
\hline
\end{tabular}

Source: Annual reports from the sample of selected Commercial Banks (2005-2019)

\section{Granger Causality Test}

The granger causality test was performed on the models to examine the direction of the causality relationship between Credit Risk and commercial bank financial performance.

Null hypothesis: $\left(\boldsymbol{H}_{\mathbf{0}}\right)$ causal relationship does not exist between credit risk and other variables on the financial performance of commercial banks in Tanzania from 2005-2019 - Accept $\boldsymbol{H}_{\mathbf{0}}$ If (Sig. F) $<5 \%$.

Alternative hypothesis: $\left(\mathrm{H}_{1}\right)$ causal relationship exists between credit risk and other variables on the financial performance of commercial banks in Tanzania from 2005-2019 - Accept $\boldsymbol{H}_{\mathbf{1}}$ If (Sig. F) >5\%

Table 8: Panel Granger causality Results

\begin{tabular}{|c|c|c|c|c|c|c|}
\hline \multicolumn{7}{|c|}{ A. Dependent variable: ROA } \\
\hline Equati & & Excluded & chi2 & df & Prob>chi2 & Decision \\
\hline ROA & 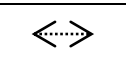 & NPLR & 9.783 & 2 & 0.008 & Reject $H_{0}$ \\
\hline ROA & $\cdots \cdots$ & LLPR & 1.3148 & 2 & 0.518 & Accept $H_{0}$ \\
\hline ROA & 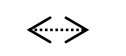 & CAR & 11.794 & 2 & 0.003 & Reject $H_{0}$ \\
\hline ROA & $\ll$ & LBAS & 14.068 & 2 & 0.001 & Reject $H_{0}$ \\
\hline ROA & $\ll$ & ALL & 34.822 & 8 & 0.000 & Reject $H_{0}$ \\
\hline \multicolumn{7}{|c|}{ B. Dependent variable: NPLR } \\
\hline NPLR & $\cdots \cdots$ & ROA & 0.53203 & 2 & 0.766 & Accept $H_{0}$ \\
\hline NPLR & 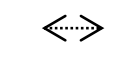 & LLPR & 13.084 & 2 & 0.001 & Reject $H_{0}$ \\
\hline NPLR & $\cdots \cdots$ & CAR & 4.6346 & 2 & 0.099 & Accept $H_{0}$ \\
\hline NPLR & $\cdots \cdots$ & LBAS & 2.5823 & 2 & 0.275 & Accept $H_{0}$ \\
\hline NPLR & 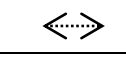 & ALL & 22.974 & 8 & 0.003 & Reject $H_{0}$ \\
\hline
\end{tabular}


East African Journal of Business and Economics, Volume 4, Issue 1, 2021

Article DOI: https://doi.org/10.37284/eajbe.4.1.478

\begin{tabular}{|c|c|c|c|c|c|c|}
\hline CAR & $\cdots \cdots$ & ROA & 2.0141 & 2 & 0.365 & Accept $H_{0}$ \\
\hline CAR & $\cdots \cdots$ & NPLR & 1.8775 & 2 & 0.391 & Accept $H_{0}$ \\
\hline CAR & $\cdots \cdots$ & LLPR & 1.9274 & 2 & 0.381 & Accept $H_{0}$ \\
\hline CAR & $\cdots \cdots$ & LBAS & 1.8649 & 2 & 0.394 & Accept $H_{0}$ \\
\hline CAR & $\cdots$ & ALL & 6.3621 & 8 & 0.607 & Accept $H_{0}$ \\
\hline
\end{tabular}

Source: Annual reports from the sample of selected Commercial Banks (2005-2019)

\section{DISCUSSION OF THE FINDINGS}

\section{The Relationship Between Non-Performing Loan Ratio (NPLR) and ROA}

Fixed effects regression NPLR had a negative coefficient (0.0855) and P-value equal to 0.011 which is not more than 0.05 level of significance as indicated in Table 6. Therefore, NPLR relates negatively to the performance of commercial banks. Thus one percent (1\%) increase in NPLR will reduce the performance of commercial banks by $8.55 \%$ ceteris paribus. This is in similarity to Boahene et al. (2012) and Kargi (2011).

\section{The Relationship Between Capital Adequacy Ratio (CAR) and ROA}

The result of regression in Table 6 showed that CAR has a significant positive relationship with ROA. The coefficients had a value of 0.0726 and a p-value of 0.000 , which is less than 0.05 . This means that if the capital adequacy ratio is increased by 1 percent while all other variables are kept constant, the return on assets is predicted to be increased by 7.26 percent in the same direction. Hence, the result was consistent with the study's expected sign.

The Long-Run Relationship Between Credit Risk and Financial Performance of Commercial Banks in Tanzania

Johansen Cointegration Test was engaged to investigate long-run causal relationships between financial performance indicators and credit risk proxies. The test results suggest that long-run relationships exist between financial performance indicators and all credit risk indicators that were used.

As presented in Table 7 of the previous chapter, at maximum rank 2, the trace statistic (88.0946) exceeds critical values (29.68). Hence, we rejected the null hypothesis and accepted the alternative hypothesis. As a result suggesting that the series variables are cointegrated. Similarly, for max statistics, the value 50.5175 exceeds the critical value of 20.97, implying that the null hypothesis can be rejected and the alternative hypothesis accepted. Thus, as per maximum rank 2, cointegrated existed to all variables, i.e., there is a long-run relationship that exists between them.

\section{The Causal Relationship Between Credit Risk and Financial Performance of Commercial Banks in Tanzania}

The findings with respect to ROA as a financial performance indicator and the credit risks, i.e., NPLR, CAR, and LBAS, except for LLPR that ROA does granger causes the credit risk proxies in the sample of commercial banks selected in Tanzania. This implies that past values of ROA can be used to predict the values on credit risks proxies, i.e., NPLR, CAR, and LBAS of commercial banks in Tanzania.

From the results presented in Table 8 previous chapter, Granger causality-Wald test suggests the evidence of bi-directional (feedback causality) between ROA to NPLR, ROA to CAR, ROA to LBAS, and NPLR to LLPR. Thus, these variables explain and imply that the financial performance and credit risk proxies can be used to predict and cause each other. 


\section{SUMMARY, CONCLUSION, AND RECOMMENDATION}

\section{Summary of the Findings}

Findings revealed that there is a co-integrating longrun relationship between credit risk proxies with that of financial performance measures of the commercial banks in Tanzania. Also, it concluded that in a panel of 15 commercial banks in Tanzania ROA that granger causes the credit risk proxies, i.e., CAR, NPLR, LBAS except on LLPR which is statistically insignificant, yet the granger causes ROA in a panel of 15 samples selected of commercial banks in Tanzania when all variables are taken together at $1 \%$ level of significance.

Furthermore, the NPLR had a significant negative relationship with ROA. This implies that a $1 \%$ increase in NPLR will result in a $12.78 \%$ decrease in ROA. Hence NPLR has a negative relationship with commercial bank performance.

Lastly, a $1 \%$ increase of CAR will result in an $8.57 \%$ increase in ROA which is statically significant ( $\mathrm{p}$ less than 0.05 ), and a $1 \%$ increase of BAS will result in a $0.14 \%$ decrease of ROA results which is statically insignificant since its $\mathrm{P}$ is greater than 0.05 .

\section{Conclusions}

In summary, it was concluded that a significant relationship exists between NPLR (showing negative relationship), CAR (showing positive relationship), and commercial banks financial performance in Tanzania. At the same time, there is an insignificant relationship concluded between LLPR, BAS, and the performance of commercial banks in Tanzania. In the long run, the research variables have a cointegrating relationship and ROA can granger cause the NPLR, CAR, BAS with the exception of LLPR, which does not granger cause ROA.

\section{Recommendations and Implication of the Study}

As concluded from the study findings, possible recommendations are detailed herein summary by the researcher were as follows;

- As a result of a negative and significant relationship established between Nonperforming Loan ratios with the performance of commercial banks in Tanzania, commercial banks should give more attention to handling credit risk. Therefore, the study recommends that the commercial banks should put more emphasis on credit risk management such as adherence to the bank's credit policy, and manage their Non-performing Loans to the minimum threshold settled by BOT.

- In this study research, four variables were used to proxies credit risk while one variable proxy financial performance. There are other variables apart from the variables used in the study that could be used to proxy both credit risk like an Expected loss as per IFRS, Macroeconomic variables, e.g., GDP, INF, and financial performance Like ROE.

\section{REFERENCES}

Afriyie, H. O., \& Akotey, J. O. (2013). Credit risk management and profitability of rural banks in the Brong Ahafo region of Ghana. Management, 5(24).

Akerlof, G. A. (1978). The market for "lemons": Quality uncertainty and the market mechanism. In uncertainty in economics (pp. 235-251). Academic Press.

Alshatti, A. S. (2015). The effect of credit risk management on financial performance of the Jordanian commercial banks. Investment management and financial innovations, 12(1), 338-345.

Anwen, T. G. L., \& Bari, M. S. (2015). Credit Risk Management and Its Impact on Performance of 
Commercial Banks: In of Case Ethiopia. Research Journal of Finance and Accounting, 6(24), 53-64.

Boahene, S. H., Dasah, J., \& Agyei, S. K. (2012). Credit risk and profitability of selected banks in Ghana. Research Journal of finance and accounting, 3(7), 6-14.

Bono, Z. B. (2020). Effect of Credit Risk on Performance of Commercial Banks in Ethiopia. International Journal of Trend in Research and Development, 7(4), 292-298.

BOT. (2010). Risk Management Guidelines. Risk Management Guidelines for banks and financial institutions. Dar es Salaam, TZ: Bank of Tanzania

BOT. (2019). Annual Report. Financial Sector Supervision. Directorate of Financial Sector Supervision, Bank of Tanzania.

Cheng, L., Nsiah, T. K., Ofori, C., \& Ayisi, A. L. (2020). Credit risk, operational risk, liquidity risk on profitability. A study on South Africa commercial banks. A PLS-SEM Analysis. Revista Argentina de Clínica Psicológica, 29(5), 5.

Daba, W. (2015). Impact of Credit Risk Management on Banks Profitability (A Case Study of Selected Private Commercial Banks in Ethiopia) (Doctoral dissertation).

Gizaw, M., Kebede, M., \& Selvaraj, S. (2015). The impact of credit risk on profitability performance of commercial banks in Ethiopia. African Journal of Business Management, 9(2), 59-66.

Hosna, A., Manzura, B., \& Juanjuan, S. (2009). Credit risk management and profitability in commercial banks in Sweden. Göteborgs universitet.

Kaaya, I., \& Pastory, D. (2013). Credit Risk and Commercial Banks Performance in Tanzania: a
Panel Data Analysis. Research Journal of Finance and Accounting, 4 (6), 55 - 61.

Kargi, H. S. (2011). Credit Risk and the Performance of Nigerian Banks. Zaria: Ahmadu Bello University Press.

Kithinji, A. M. (2010). Credit Risk Management and Profitability of Commercial Banks in Kenya. School of Business, University of Nairobi, Kenya.

Kolapo, T. F., Ayeni, R. K., \& Oke, M. O. (2012). Credit Risk and Commercial Banks' Performance in Nigeria: A Panel Model Approach. Australian journal of business and management research, 2(2), 31.

Laar, J. N. \& Adjei, L. N. (2020). Assessing the Effects of Credit Risk Management on Financial Performance of Selected Banks in the Ghana Stock Exchange. Research Journal of Finance and Accounting, 11 (12), 79-100.

Li, F. \& Zou, Y. (2016). The Impact of Credit Risk Management on Profitability of Commercial Banks: A Study of Europe. Umeå School of Business and Economics, Sweden.

Lotto, J. (2018). Assessing the impact of nonperforming loans on profitability of Tanzanian banks. European Journal of Accounting, Finance and Investment, 4 (10), 12-21.

Mengistu, M. (2018). The Effect of Credit Risk Management on Profitability of Selected Commercial Banks in Ethiopia. St. Mary's University, Ethiopia.

Munangi, E., \& Bongani, A. (2020). An empirical analysis of the impact of credit risk on the financial performance of South African banks. Academy of Accounting and Financial Studies Journal, 24(3), 1-15.

Poudel, S. R. (2018). Impact of credit risk on profitability of commercial banks in 
East African Journal of Business and Economics, Volume 4, Issue 1, 2021

Article DOI: https://doi.org/10.37284/eajbe.4.1.478

Nepal. Journal of Applied and Advanced

Research, 3(6), 161-170.

Takang, F. A., \& Ntui, C. T. (2008). Bank performance and credit risk management. Unpublished Masters Dissertation in Finance, University of Skovde.

Tuladhar, R. (2017). Impact of credit risk management on profitability of Nepalese commercial banks. Western Sydney University. 